\title{
REGENERATION AND DEMOLITION VIS-Á-VIS DISINTEGRATION OF URBAN SPACE: THE CASE OF EL CABANYAL-CANYAMELAR IN VALENCIA
}

\author{
${ }^{1}$ Urban Regeneration Laboratory \\ Institute of Urban Geography and Tourism Studies \\ Faculty of Geographical Sciences \\ University of Łódź \\ Kopcińskiego 31, 90-142 Łódź: Poland \\ e-mail: jaroslaw.kazimierczak@geo.uni.lodz.pl \\ ${ }^{2}$ Valenthia Strategy SL \\ Architecture Studio in Valencia \\ C / Moratin 1511 46002, Valencia: Spain \\ e-mail: karolinajoannawrona@gmail.com
}

Jarosław Kazimierczak ${ }^{1}$ (D) Karolina Wrona ${ }^{2}$

\begin{abstract}
Disintegration of urban space is the opposite of its organisation; regeneration should be discussed in this context as it restores or introduces morphological attributes that meet the needs of local communities. The paper identifies the impact of regeneration upon urban space (re)integration and the role of planned demolition as a regeneration tool on the example of el Cabanyal-Canyamelar district in Valencia, Spain. Studies have demonstrated that demolition can be considered a rational component of regeneration and that not only morphological attributes of the transformed area are important for urban space regeneration but also intentions and ways of using demolition as a regeneration tool.
\end{abstract}

\section{Key words}

disintegration of urban space - dysfunctionality - regeneration $\bullet$ demolition $\bullet$ el Cabanyal-Canyamelar • Valencia

\section{Introduction}

Social changes taking place in a specific urban community are direct causes of functional transformations in cities. The latter, in turn, determine changes in urban morphology initiated when architectural and urban forms fulfilling specific economic and social functions are no longer acceptable by local people and other city users. As a result, they 
must either be adapted to new functions, reconstructed or created anew, which often happens through the elimination of the existing forms. Klassen (1988) claims that a city is created by urban and social subsystems, which although autonomous, are linked with each other and work together in a feedback loop. According to him, urban development exhibits inertia and changes in urban structure are lagging behind the changes in society. This is why discrepancy between the properties of urban morphology and needs and requirements of local communities accumulate. These inconsistencies either initiate or foster disintegration in a city whose space and its organisation constantly evolve together with changing political, economic, social, cultural and natural conditions.

Our studies provide theoretical, methodological and empirical insight into disintegration as a process of urban space transformations and their outcomes. Considerations on urban space transformations are set in the regeneration context and focus on radical form of the process, in which planned demolition is a tool for solving spatial, social, cultural and economic problems (Kaczmarek et al. 2018). Our goal was to demonstrate: (1) the impact of regeneration projects upon disintegration and (re)integration of urban space, and (2) the relevance of planned demolition in the process, in other words, can it be a rational tool of regeneration aiming at the (re)integration of the city? For our in-depth studies we selected the district el Cabanyal-Canyamelar in Valencia, Spain, which, as a degraded urban area, since the late 1990s had been a living laboratory of tabula-rasa approach to regeneration (Jones \& Evans 2008). At the same time, el Cabanyal-Canyamelar illustrates the problem of disintegration observed in cities across the world. In line with the logic of a case study deployed as a research method, the fact that we are dealing with a single case, which is rather common justifies generalising it over to other cases (Yin 2014).

\section{Urban space disintegration: substance}

Disintegration weakens the integrity of structures or makes them fall apart. The list of synonyms of disintegration includes, inter alia, atomisation, decomposition, fragmentation, division, segmentation, decay, and break-up. Since a city should be perceived as a complex morphological system - visible outcome of cumulated activities of subsequent generations of communities living in a particular territory - urban disintegration takes place at three levels, which altogether make the urban space. Maik et al. (2005) distinguish the morphological level, in which spatial layout of morphological elements organises urban functions; the functional level, meaning the distribution and mutual impact of various urban activities; and the social level as a distribution of people across the city. We need to view the substance of urban disintegration through the lens of urban space organisation. The term 'organisation' derives from the Latin word organum and Greek organom, which mean a 'tool'. Informally, organisation means logic, order and a sequence of actions. Kotarbiński (1965) argues that organisation is a kind of entirety due to its own elements' relationship to it, namely, the entirety where all components contribute to the success of the entirety. Urban space organisation means that morphology and functional structure meet the needs of its users. According to Liszewski (2012) urban space can be considered organised as long as it is divided (fragmented) adequately to local needs, connected/installed (equipped with utilities), used in functional terms (utilised), and then developed (built-up) in a way that serves local needs. Disintegration weakens the integrity or dismantles spatial, functional and social structures. As a result, we get an urban space, where the development and functions of its parts or of the whole of it do not meet the needs of city users, which produces urban dysfunctionality. In this approach, dysfunctionality is the opposite of urban space 
organisation and should be equalised with disintegration (the state rather than the process).

Dysfunction means abnormality or inadequacy for performing specific functions. Dysfunction of an element must be related to a bigger entirety, in which the element performs a function (role, task) assigned to it. In a city, functionality expresses itself through morphology that enables specific urban activities. When a given component ceases to perform the function (role, task) or starts performing it incorrectly, in a way that is inadequate to the reality around, the component loses its raison d'être in its current shape as it undermines effective performance of the entire unit (Kazimierczak 2017). In urban areas we are dealing with contextual dysfunction, conditioned with morphological, social, and cultural attributes of the location. Since urban space layout evolves, dysfunctionality interpreted as a mismatch between spatial and functional structure (urban subsystem) and local population needs (social subsystem) also evolves.

Dysfunctional (disintegrated) areas can be very much differentiated when it comes to their morphology (spatial and functional aspects). They may be simple linear morphological elements (a road, a street), spots (monuments and obelisks), surfaces (plots, non-built areas, squares) or buildings, as well as complex forms that make blocks and districts. Buildings and urban plots act as disintegrators (barriers) if they are not used (urban idle land, squats), degraded (devastated, ruined, demolished), or appropriated and used in a way inconsistent with their destination (e.g., squares and green areas used as parking places, buildings turned into squats). Streets and roads in the city normally join its different parts but they may also create barriers hard to overcome both physically and psychologically. It is confirmed by studies of, e.g., Coudroy de Lille (2003), who points to 'unfamiliarity' and 'distance' of the Confluence region in Lyon caused by the course of the motorway and the railway route, which separate the district from the historic city centre. Similar conclusions from studies on the perception of urban landscape within the framework of general idea of a place developed by human geography were drawn by, e.g., Gould \& White (1974), Paasi (2004), Relph (1976), and Tuan (2001). Disintegration can also be produced by too big buildings, which do not match the urban context (Lynch 1960; Tobiasz-Lis \& Wójcik 2013a, b).

Dysfunctionality of complex forms depends on the concentration of simple morphological elements acting as disintegrators. There are social groups who perceive spaces used (available) in a selective way, exclusive public space included, as disintegrating elements (Kaczmarek 2010, 2012). Another morphological disintegrator can be big urban blocks with no business activity, which gradually turn into 'economically idle' areas, a serious problem in many city centres. For instance in Łódź, Poland, where in order to introduce services into the city centre to bring it back to life, new passages or streets had to be created inside the blocks (Kazimierczak \& Kosmowski 2017). Also the shape of individual blocks may pose a barrier for, e.g., traffic organisation and the structure of public space, which is crucial for smooth performance of multifunctional areas, especially city centres.

Disintegrators (barriers) in cities can emerge as a result of social changes, such as urban areas being occupied by communities of different cultures, religions, ethnicity or race. The process produces social segregation, creates ghettos often closed for other communities and 'no go zones'. The absence of the sense of security has produced gated residential developments (gated communities) (e.g., Carvalho et al. 1997; Blandy \& Lister 2005; Brabec \& Machala 2015). Conflicts leading to social segregation in space may also be due to gentrification, both bottomup as understood by Ruth Glass (1964) and top-down, initiated by local authorities (stateled) and developers (Bourne 1993; Lees 2003; Clarke 2005; Davidson \& Lees 2005). In literature extreme forms of disintegrated cities are referred to as divided cities (Allagra et al. 2012) and are often politically conditioned 
(Calame \& Charlesworth 2012; Slae et al. 2012; Dumper 2013; Aquilué \& Roca 2016). In this approach, we are dealing with social dysfunction (disintegration) of urban areas reflected in their morphology by walls, borders, idle areas, etc. Culturally, disintegration of a city manifests itself in a dissonance between the real and expected development of the city (or of its part) projected in human imagination as well as in individual and collective perception. It may also be a disruption of the continuity of a specific 'place' and its social, economic and symbolic function. Disruption of continuity may occur rapidly through, e.g., destruction or demolition or, when the process is distributed over time, it becomes sequential and evolutionary. Then it creates 'non-places' as understood by Augé (1995) and Tuan (2001) and links with the loss of mémoire collective (Halbwachs 1992) and, consequently, with the loss of identity of communities living in specific (parts of) cities. Divisions in cities are also connected with obelisks and monuments (Muszyńska 2013), i.e., morphological landmarks, which are important, symbolic elements in urban public space (Kazimierczak 2010).

As a result of theoretical and conceptual considerations we need to assume that a disintegrated area is an area where urban space is disorganised (dysfunctional) at morphological level. Its opposite is an integrated area where morphology and functional structure meet users' needs, an area not suffering from social conflicts motivated by economic, religious, racial, ethnic, national factors, which create morphological elements that divide space.

Public space is the key integrating element for urban space. If well developed and inclusive, public space fosters identification with the city and the sense of belonging to the local community (Majer 2016). Public space is decisive for the shaping of identity of urban populations (Wallis 1990) and acquires an almost symbolic dimension if we think of the city centre (Jałowiecki \& Szczepański 2010). High quality of public space increases the likelihood of optional activities (Gehl 2011), which favour establishing relations and strengthening social bonds. Poorly developed, low quality public space as well as exclusive public space lead to the selective use and restrict users' activities to primary (necessary) ones.

\section{Disintegration of urban space as a challenge to regeneration}

Dysfunctional (disintegrated) urban areas are natural components of spatial, functional, social, and cultural transformations. However, if they last long they generate barriers to growth and distort smooth performance of a city as a functional unit. Dysfunctional territories, as barriers to growth in themselves, undermine the potential of their neighbouring areas to fully tap into their growth perspectives, which, in turn, slows down the growth of the city. Progressing disintegration creates urban areas that rank at the bottom of urban hierarchies because they are centres of negative economic, and social phenomena and get degraded gradually but relatively quickly (Kazimierczak 2017). In this approach, degradation is derivative of disintegration and dysfunctionality. In order to prevent degradation of urban areas, dysfunctional territories necessitate remedy action to restore their smooth performance. This remedy consists in regeneration, which aims at introducing (or possibly restoring) organisation into urban space by adapting spatial and functional structure to local users' needs. Regeneration takes place through elimination of morphological disintegrators. In degraded urban areas tackled with disintegration, regeneration is supposed to eliminate negative social and economic phenomena through morphological transformations and other activities that target people (users, residents). Relationships between disintegration, dysfunction, degradation and regeneration are illustrated in Figure 1.

Szmytkowska (2016) draws attention to the threat to the integrity of cities hidden in regeneration projects. It is connected with the need to reconcile public interest and economic calculations, which in the age 
State $t$ : : ORGANIZED URBAN SPACE (state)

Space is well: divided, connected, functionally used, developed.

Space is properly (adequately) organized = urban subsystem matches the social subsystem.

\section{DISINTEGRATION (generation of disintegrators)}

Disintegrator is a simple or complex component of urban morphology causing disintegration (dysfunctionality) of urban area.

Simple morphological disintegrators: empty buildings and idle urban plots, degraded buildings, buildings and urban plots appropriated or used contrary to their original function, overscaled buildings and streets (roads), lots used for non-urban functions, buildings and plots for exclusive uses, conflict-generating obelisks and monuments, walls, fences, enclosures, etc.

Complex morphological disintegrators consist of a set of simple morphological disintegrators.

State $t 2$ : DYSFUNCTIONALITY = DISINTEGRATION (state)

Space incorrectly: divided, connected, functionally used, developed.

Space improperly (inadequately) organized = urban subsystem does not match the social subsystem.

DEGRADATION (impact of disintegrators and depreciation of a region in urban hierarchy)

Degradation is a spontaneous, unplanned and uncontrolled process of the loss of value (tear and wear) of urban substance caused by evolving user needs and increasing discrepancy between urban subsystem (urban morphology) and social subsystem.

Degradation changes the development of (part of) the city and impacts political, social and economic context of its immediate and distant neighbourhood.

In a wider sense, degradation can also be interpreted as unplanned demolition distributed over time, unlike, e.g., planned demolition usually consisting in radical intervention within a short time span.

\section{State $\boldsymbol{t} 3$ : DISINTEGRATION (state)}

Space with concentrated negative social and economic occurrences caused by progressing disintegration, i.e., accumulation of simple and complex morphological disintegrators.

Space improperly (inadequately) organized $=$ urban subsystem does not match the social subsystem.

\section{DISINTEGRATION / \\ DEGRADATION / \\ REGENERATION?}

State $t \mathbf{4}:$ ?

What is the conditon of urban space?

Time ( $t)$

\section{REGENERATION (elimination of} disintegrators)

Regeneration of dysfunctional (disintegrated) areas is expected to introduce (or restore) urban space organisation, i.e., to adjust the morphological (spatial and functional) structure to urban (user) needs through the elimination of morphological (barriers) disintegrators. It can take:

- adaptative form by transforming and adjusting the existing barriers to current user needs; - radical form when barriers are demolished and new spatial and functional forms are shaped.

State $t 3$ : ORGANIZED URBAN SPACE (state) Space is well: divided, connected, functionally used, developed.

Space is properly (adequately) organized $=$ urban subsystem matches the social subsystem.

REGENERATION (social and economic revival) Regeneration of degraded areas is a sequence of planned activities designed to socially and economically revive problem urban areas through the transformation of their spatial and functional structures.

If no regeneration efforts are made in dysfunctional area, regeneration also entails elimination of morphological disintegrators (barriers) through: - adaptative approach by transforming and adjusting the existing barriers to current user needs;

- radical approach through demolition of barriers and shaping new spatial and functional forms.
State $t 4$ : ORGANIZED URBAN SPACE (state)

Space is well: divided, connected, functionally used, developed.

Space is properly (adequately) organized = urban subsystem matches the social subsystem.

Figure 1. Relationships between organised, dysfunctional and degraded urban space and disintegration, degradation, and regeneration 
of neoliberal economy provide the main guidelines to investors and city authorities. In this specific 'game' played in urban space residents of transformed areas are the most vulnerable (Swyngedouw et al. 2002). The key to (re)integration of regenerated area with the city lies in the engagement of local community in planning (Kaczmarek 2001, 2003). It is also vital to provide spatial and architectural continuity that would blur clear-cut borders between morphological, economic, social, and cultural barriers. The so called flagship projects raise some concerns as their implementation in regenerated areas often leads to the deepening of differences between parts of the city (Gibson 2003), which may generate competition among them (Kazimierczak 2014).

Currently implemented projects of urban space (re)integration, which restore or introduce organisation into urban space, have been developed based on two models of spatial and functional transformations carried out as part of regeneration efforts. Both entail the need to adjust urban and architectural forms to evolving economic and social functions (Kazimierczak 2014, 2016). These are adaptation transformations with minimum interferences into the morphology of the area as well as radical actions of tabula-rasa type (Jones \& Evans 2008) where problems are resolved through planned demolition of the existing spatial and functional structure. Despite high social (e.g., social disruption) and cultural (e.g., loss of parts of historic buildings) costs, planned demolition is increasingly more often used as a regeneration tool. As demonstrated by examples of contemporary regeneration projects, e.g., in French cities, planned demolition as a remedy instrument in urban policy may help solve social, cultural, and economic problems (Kaczmarek et al. 2018). Moreover, Lévy \& Lussault (2014) argue that from urban planning point of view, demolition provides dynamics into urban modernisation if it is accompanied by reconstruction. Perceived from this angle, demolition may become a crucial element in eliminating disintegrators from urban space. The core of the process is demolition of buildings and premises, which are no longer used or got decapitalised or are used differently from what they were intended for and to replace them with forms that meet present needs of local communities (users). Demolition of the material substance of a city may target simple morphological elements and complex structures. Demolition enables not only (re)integration along spatial and functional lines but also at economic, social, and cultural levels. The above quoted example of France shows that demolition applies to premises and buildings tackled with pathologies, such as drugs or criminality. At this point, we need to highlight the contextual aspect of demolition as component of regeneration; similarly to disintegration and dysfunctionality, demolition is conditioned by morphological, social, and cultural merits of the place in question: a city, district, block or a single building in urban space.

In a top-down regeneration process, either adaptative or radical, the wish to implement the project often overshadows the interest of local communities living in the area or using it. Often such projects are delivered without the participation of local people. They are financed from public funds, possibly with the participation of commercial partners, and are mostly large-scale (mega) projects.

\section{Research: scope, methods, and materials}

Our case study discusses disintegration of urban space using el Cabanyal-Canyamelar, the eastern district of Valencia, Spain, situated on the coast of the Mediterranean as an example. The district is located $5 \mathrm{~km}$ away from the city centre. At present, it is inhabited by ca. 20,500 people (Navarro Elsava 2016). Its origins date back to the 15th century. The district comprises three morphologically homogenous units extending longitudinally: Cap de França, el Cabanyal, and el Canyamelar. Contemporary official documents use the name el Cabanyal-Canyamelar. 
Disintegration of the district became an issue in the second half of the 20th century with territorial expansion of Valencia when el Cabanyal-Canyamelar was 'incorporated' into the city (Muños Cosme 2012). In the 1980s and 1990s it suffered from crisis in the fisheries sector, the primary source of income of the local community. The district got depopulated (from 26,179 in 1981 to 20,170 in 2017) and local people got impoverished. Disintegration of the district was also caused by other three factors: decapitalisation of the housing stock, including monumental buildings from the 19th and 20th centuries built in Art Nouveau, Art déco and modernist styles, called alquerias, which are typical of this district and make it unique in Valencia (Navarro Elsava 2014); lack of functional and compositional element that would link el Cabanyal-Canyamelar, a district of clearly different morphology than its neighbouring areas (small plots and smaller blocks of longitudinal shape, densely built-up, time of construction); and the multilane Avenida de Serrería the capacity of 1,500-3,000 cars per hour, which provides a clear border and spatial-functional barrier between el CabanyalCanyamelar and the neighbouring districts. External disintegration of el Cabanyal-Canyamelar comes from the harbour and postharbour areas located south of the studied area, as well as idle post-railway areas in the eastern part of the district (Fig. 2).

From the late 1990s el Cabanyal-Canyamelar has been the area where different strategies (models) of regeneration have been implemented to integrate the district with the rest of Valencia. Studies pay

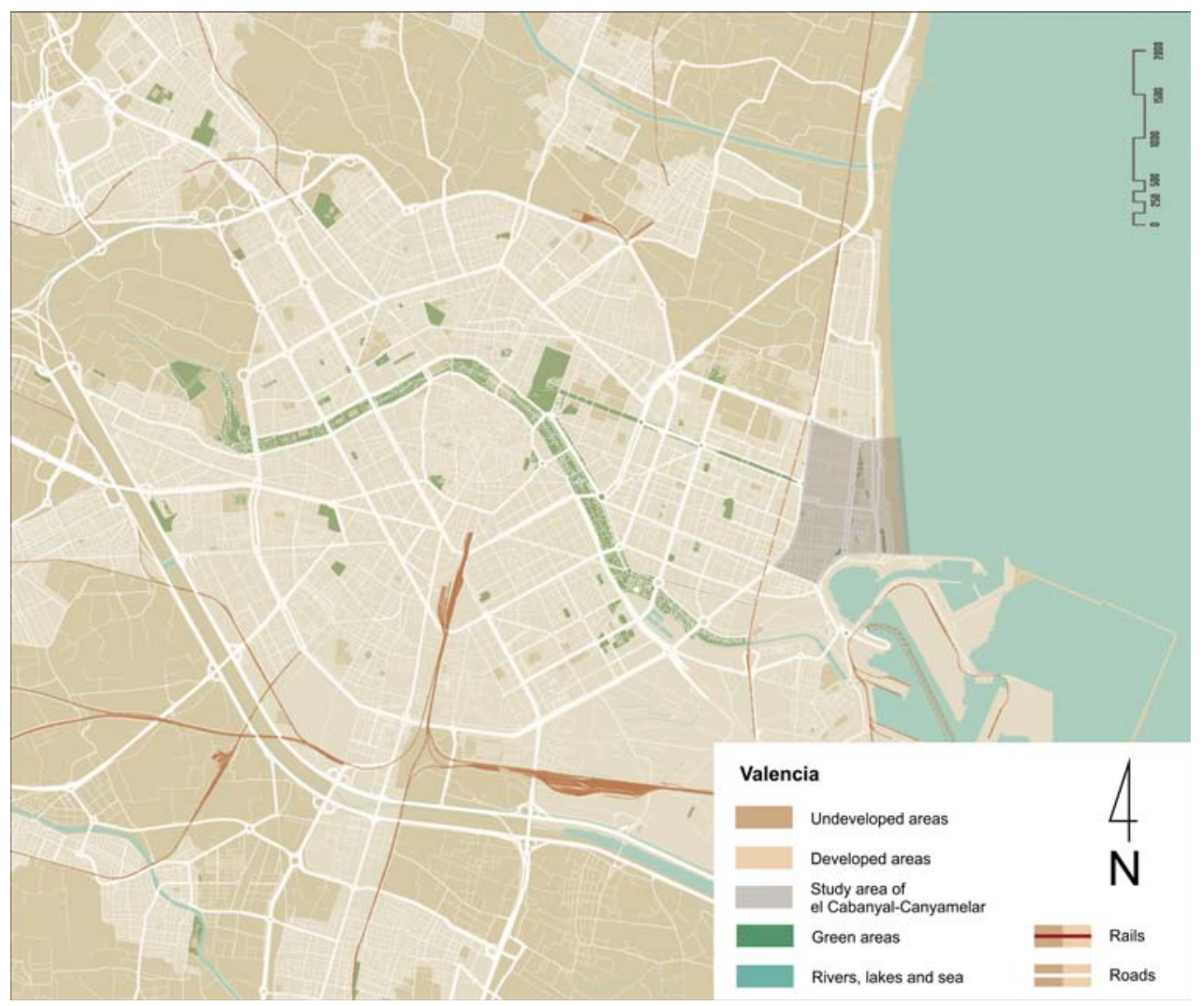

Figure 2. El Cabanyal-Canyamelar: location within the Valencia spatial structure 


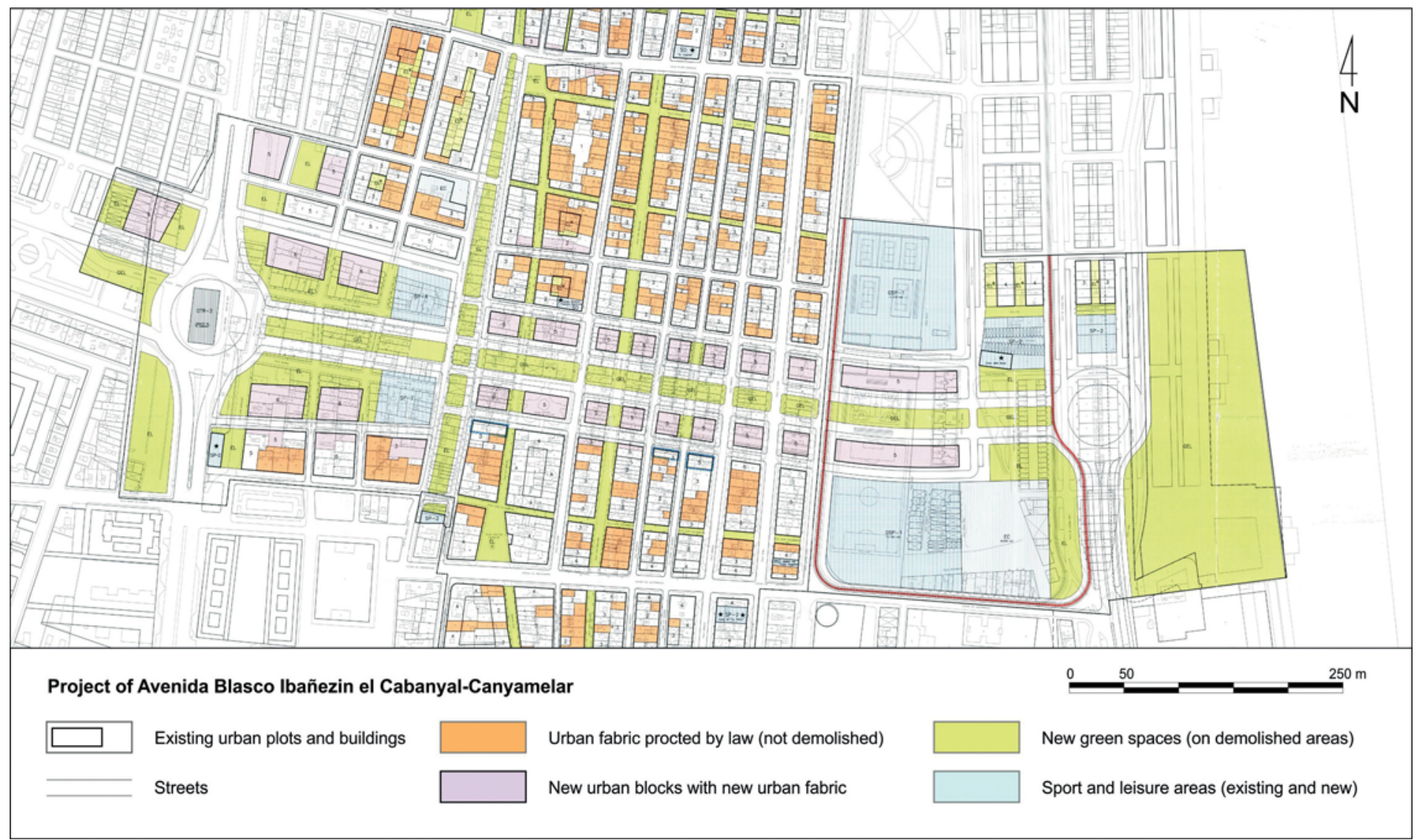

Figure 3. Morphological transformations planned in the central part of el Cabanyal-Canyamelar due to the construction of Avenida Blasco Ibañez and the implementation of the Cabanyal 2010 regneration plan

Source: Author's own compilation based on the PEPRI el Cabanyal-Canyamelar. Ordenacón. Plano 2 Hoja 2 Centro. Réimen urbanístico. Marzo 2001. Ajuntamient de València. AUMSA. 
special attention to regeneration megaprojects, which assumed modernisation and integration of the district carried out through demolition (tabula-rasa regeneration). We decided to conduct the survey to show: (1) the impact of regeneration projects upon disintegration and (re)integration of urban space, and (2) the importance of planned demolition, in other words, can it be a rational tool in regeneration undertaken to re-integrate the city?

El Cabanyal-Canyamelar case study provides grounds for analytical generalisation. Its task consists in formulating general conclusions based on results of empirical studies and generalising them to other contexts, outside of the case at hand, relying on the correctness of data or theoretical principles (Yin 2014). Data for empirical explorations used in the study came from primary and secondary sources. Secondary sources of data are statistical analyses offering social, economic and spatial data. We also conducted desk studies of historical and contemporary cartographic sources, documents, research and popular press papers devoted to el CabanyalCanyamelar regeneration since the 1990s. In September 2016 and 2017 the above mentioned data were complemented with field studies intended to make field inventory and provide photo documentation. We also used in-depth interviews conducted in 2016 with local authorities, city planners, representatives of NGOs, residents of Valencia and el Cabanyal-Canyamelar.

\section{Regeneration of the dysfunctional district of el Cabanyal- -Canyamelar: course and effects}

El Cabanyal-Canyamelar regeneration plan titled Cabanyal 2010 was part of the megaproject called PEPRI'. It provided for the extension of the Avenida Blasco Ibañez avenue eastwards from Avenida de Serrería

1 PEPRI, i.e. Plan Especial de Protección y Reforma Interior (Special Plan of Protection and Transformation of Interior Areas of the City) was adopted by the local government in Valencia in 1998. to the seafront (Fig. 3). The origins of Avenida Blasco Ibañez date back to the late 19th when el Cabanyal-Canyamelar was incorporated into administrative borders of Valencia. Local authorities wanted to carry out an ambitious project of joining the Jardines del Rey (Royal Gardens) in the city centre (Fig. 2) with the seafront by building a chic boulevard. The construction project was carried out in stages starting in the 1930s. Between the centre and el Cabanyal-Canyamelar it passed mostly through the then non-built areas which underwent urbanisation together with territorial expansion of Valencia in the second half of the 20th century. The final $800 \mathrm{~m}$ long part, the width of up $100 \mathrm{~m}$ was the biggest planning challenge of PEPRI and the Cabanyal 2010 project. It required the demolition of ca. 1,600 flats in the central part of el Cabanyal-Canyamelar. The project assumed the demolition of the historic buildings and led to significant modifications of the 19th century spatial layout. Some demolitions were dictated by the shape of blocks, which were longitudinal. Cabanyal 2010 plan also included several demolition efforts outside of the areas of the future boulevard to loosen the density of built-up areas and introduce green spaces. The project was supposed to be accompanied by a comprehensive modernisation of urban space in el Cabanyal-Canyamelar, e.g., renovation of degraded urban housing stock, rehabilitation of public space, introduction of green areas along streets, organising pocket parks, playgrounds for children and gardens inside the blocks to foster social relationships among local communities (Fig. 3). Upon the completion, the project was expected to deliver a functional and compositional component, Avenida Blasco Ibañez, that would link el Cabanyal-Canyamelar with Valencia and improve the quality of housing stock in the district through its modernisation and by improving the quality of public space.

The construction of Avenida Blasco lbañez, the first stage of the Cabanyal 2010 plan, started in 1998 when PEPRI was adopted by urban authorities. However, because of significant interference into the morphology 


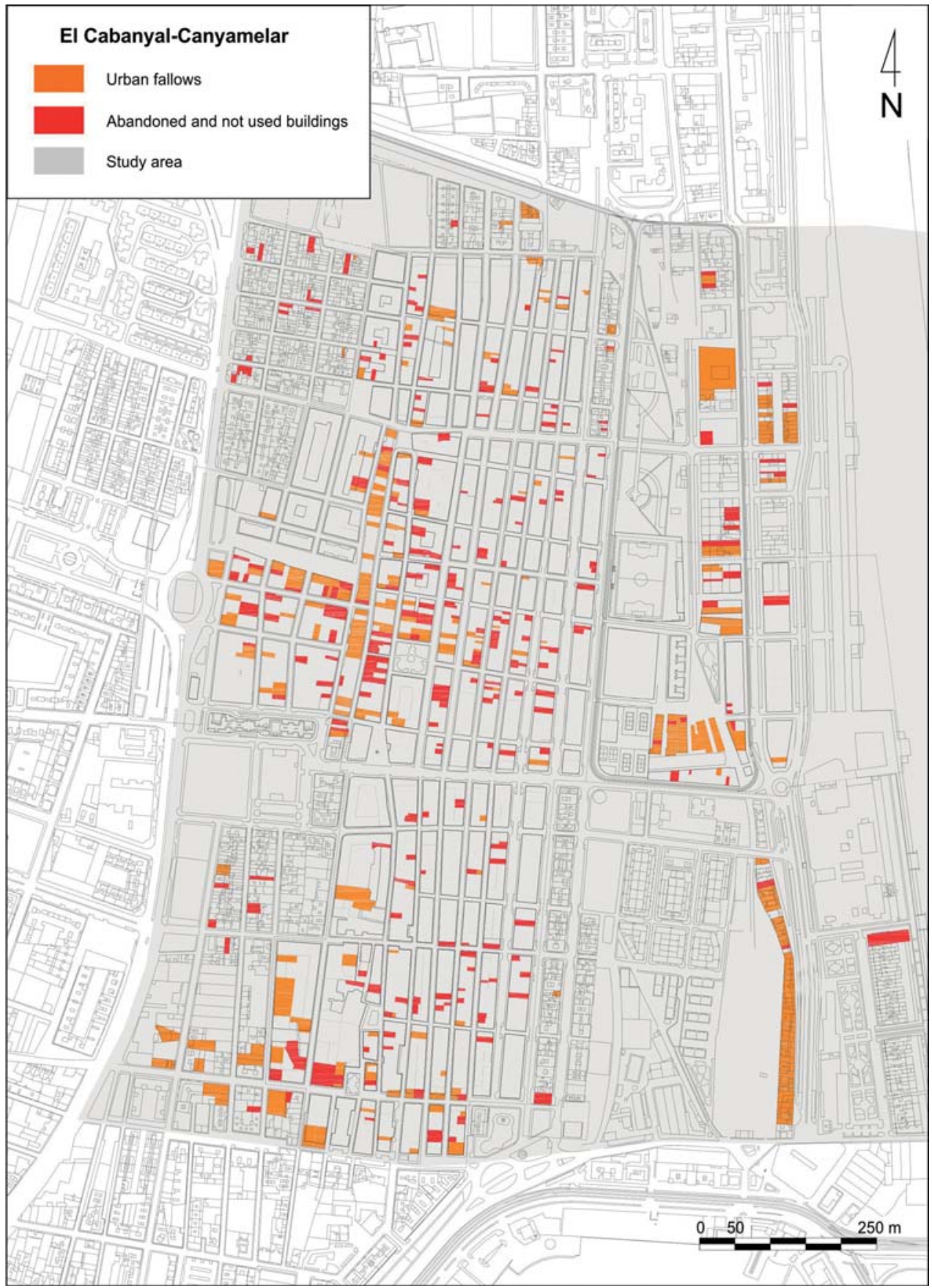

Figure 4. Empty building structures (abandonades) and urban fallows (solares) in el Cabanyal-Canyamelar in 2014

Source: Authors own compilation based on E.D.U.S.I. (2015). 
of the district, PEPRI faced powerful opposition of the then urban planning circles (Beltran 2010). As a result of social movements collectively referred to as 'Salvem el Cabanyal'(Save el Cabanyal) who invoked the "right to the city" idea (Lefebvre 1996; Purcell 2001, 2002; Mitchell 2003; Harvey 2008, 2012; Marcouse 2009), of the critique expressed by the European Union and, finally, of the interference of the Spanish central government, in 2016, the district was covered by the Special Protection Plan (PEC 2016), which led to the suspension of PEPRI and the Cabanyal 2010 project (Navarro Elseva 2014). Nevertheless, until that happened, 600 buildings over the planned course of Avenida Blasco Ibañez had already been demolished.

Implementation of the first stage of this megaproject produced two outcomes: a social one and a morphological one. The project displaced almost 200 families, most of them closely emotionally connected with the location as they were brought up there. That disrupted multigenerational bonds already developed among the neighbours (Campos 2008; López Nicolás \& Bodí Ramiro 2009). Owners and tenants of houses taken over by the local administration received small financial compensation, insufficient to purchase a flat in the same neighbourhood. The Cabanyal 2010 project was carried out in the times of prosperity in the Spanish real estate market (Miralles \& Garcia 2013; Estaban \& Altuzarra 2016; Díaz \& Araujo 2017;) when prices of apartments skyrocketed. The trend was observable for a short time, but it was dynamic and reached its peaks in the times of the displacement exercise. Thus, displaced people were forced to move to other districts in the city which is why el CabanyalCanyamelar got partly depopulated. Over the years 1998-2010, that is when the Cabanyal 2010 project was actually carried out, local population shrunk by ca. 2\% (Oficina d'Estadística Valencia), which led to decreasing tendencies in real estate prices, typical of the first stage of gentrification. It was a component of a purposeful policy because local authorities wanted to create an attractive housing and leisure area in the seafront and 'remove' the most economically vulnerable members of local communities who are potentially the most troublesome.

From urban planning viewpoint, the suspension of the construction of Avenida Blasco Ibañez prevented the emergence of spatial and functional link between el CabanyalCanyamelar and Valencia city centre. Other repercussions of the Cabanyal 2010 project included negative changes in the morphology of the district, which have exerted a significant impact upon the present development of el Cabanyal-Canyamelar and the way it is used. Since according to the plan areas alongside Avenida Blasco Ibañez were to host residential buildings and offices, some of them high rise buildings, urban plots located within the zone to be transformed became stakes in land speculation game played by local authorities and private investors (Navarro Elseva 2014). It was intensified by the displacement policy and demolition of historic housing stock. Implementation and then the suspension of the Cabanyal 2010 project increased the number of abandoned although not yet demolished houses (abandonades) and idle land (solares) recuperated after planned demolitions within the proposed course of Avenida Blasco Ibañez (Tab. 1). Their concentration in the centre of the district (Fig. 4) significantly reduces the quality of historic landscape of the neighbourhood and exacerbates the loss of social function in ruined public space. These transformations generated areas where business activities are very limited and overlap with blocks with high concentration of idle land and squats (Fig. 4). At the same time, the proportion of decapitalised housing stock in the area covered by planned demolitions clearly increased. Buildings taken over by local administration got derelict as a result of suspended investment effort and intentional policy of local authorities, which wanted to encourage those who opposed the construction plan to re-launch the investment. Abandoned buildings got gradually occupied 
Table 1. El Cabanyal-Canyamelar development in 1998 and in 2014

\begin{tabular}{|c|c|c|c|c|c|c|c|c|}
\hline \multirow{2}{*}{ Type of construction } & \multicolumn{4}{|c|}{1998} & \multicolumn{4}{|c|}{2014} \\
\hline & Number & [\%] & $\begin{array}{l}\text { Surface } \\
{\left[\text { in } \mathrm{m}^{2}\right]}\end{array}$ & [\%] & Number & [\%] & $\begin{array}{l}\text { Surface } \\
{\left[\text { in } \mathrm{m}^{2}\right]}\end{array}$ & {$[\%]$} \\
\hline $\begin{array}{l}\text { Buildings in bad technical } \\
\text { condition (total) }\end{array}$ & 243 & 7 & 28,942 & 5 & 400 & 11 & 43,747 & 7 \\
\hline Residential & 138 & 4 & 14,104 & 2 & 258 & 7 & 26,366 & 4 \\
\hline Residential and services & 105 & 3 & 14,838 & 3 & 138 & 4 & 15,840 & 3 \\
\hline Services & 0 & 0 & 0 & 0 & 4 & 0 & 1,541 & 0 \\
\hline $\begin{array}{l}\text { Undeveloped urban plots } \\
\text { (solares) }\end{array}$ & 214 & 6 & 59,976 & 10 & 366 & 10 & 105,048 & 17 \\
\hline Public ownership & 52 & 1 & 9,142 & 1 & 128 & 4 & 20,317 & 3 \\
\hline Private ownership & 162 & 5 & 50,834 & 9 & 238 & 7 & 84,731 & 14 \\
\hline $\begin{array}{l}\text { Buildings in good technical } \\
\text { condition (total) }\end{array}$ & 3,035 & 87 & 538,636 & 85 & 2,755 & 78 & 478,759 & 76 \\
\hline Total number of urban plots & 3,492 & 100 & 627,554 & 100 & 3,521 & 100 & 627,554 & 100 \\
\hline
\end{tabular}

Source: Authors' own research based on E.D.U.S.I. (2015).

by the homeless, drug addicts and squatters, which reduced the sense of security in the neighbourhood and seriously deteriorated the image of el Cabanyal-Canyamelar (Navarro Elseva 2014). Social degradation stigmatised local communities. Remaining buildings were also degraded as their owners did not renovate them in the face of potential re-appropriation by the authorities.

The idea of el Cabanyal-Canyamelar regeneration, like other peripheral areas of the city, into a highly attractive seafront investment zone (Prytherch \& Boira Maiques 2009) coincided with the implementation of the development policy of the city of Valencia intended to transform it into a 'megaevents city' (del Romeo Renau \& Trudelle 2011). The idea was an aftermath of the so called 'Barcelona effect', i.e., a dynamic economic growth of Barcelona after the city hosted the Summer Olympics in 1992. As argued by, inter alia, Andranovich, Burbank \& Heying (2001), Miller (2000), and Roche (1992, 2000), the growth was connected with increased investment and tourist attractiveness of Barcelona induced by better recognisability and image of the city. By the end of the 1990s, the government of Partido Popular promoted a spectacular urban development through land deregulation (Gaja \& Díaz 2002) and attracted private investment through a policy of megaprojects like 'City of Arts and Sciences' (or Ciudad de las Artes y las Ciencias [CAC] in Spanish) and the organisation of mega-events (Navarro Elseva 2014). In the first decade of the 21st century, two such events were held in Valencia and they have induced remarkable spatial and functional transformations in el CabanyalCanyamelar. The city hosted two editions of America's Cup ${ }^{2}$ in 2007 and in 2010, for which the old port was rebuilt and a marina was constructed in Poblats Marítims. At that time, the symbol of the competition Veles e Vents was erected - a pavillion designed as a VIP view point, which in a specific way 'opens up' Valencia into the sea. Reconstruction of the seafront in el Cabanyal-Canyamelar that accompanied the organisation of America's Cup entailed some demolition of the historic buildings in the prominent

\footnotetext{
${ }^{2}$ America's Cup is an international sailing regatta of sea-going yachts, organized since 1851.
} 
seafront. At plots 'freed' in this way, a fivestar Las Arenas hotel has been built whose façade does not match the historic alquerias inhabited predominantly by low-middle class working people. In the years 20082012 Valencia hosted also the Formula One European Grand Prix races organised on the new urban street circuit $^{3}$ built in the western area of the old port and on the post-industrial areas between el Grau and el CabanyalCanyamelar. Although these mega-events have improved the position of Valencia in the global settlement network and aroused tourists' interest in the city, it entailed substantial social and spatial costs, including a number of re-appropriations and demolition of historic buildings. They also increased prices of property in el Cabanyal-Canyamelar (Tab. 2), planned, top-down gentrification and social tensions within the district, leading to many conflicts between local residents and city authorities (del Romeo Renau \& Trudelle 2011). An important conflict factor was also produced by the growing NIMBY effect (del Romeo Renau \& Lozano 2015) generated by bottom-up urban movements, which often oppose the proposed development in their respective residential areas although they generally support such projects if they were built in other locations. The construction of Formula One racing circuit, which currently remains unused, has introduced urban idle land (farrow) of a substantial size into Valencia's spatial and functional structure. At morphological and psychological level, it makes the isolation of el Cabanyal-Canyanelar even deeper.

The inflow of troublesome social groups, drug addicts, squatters, homeless people and illegal immigrants into abandoned houses, on the one hand, and the arrival of affluent gentrifiers attracted by mega-events on Valencia seafront in the early 21 st century (America's Cup in 2007 \& 2010 and Formula

\footnotetext{
${ }^{3}$ Valencia Street Circuit with a length of $5.419 \mathrm{~km}$ is one of the two F1 tracks in the world (next to Monte Carlo), where competitions take place on the city road system. The $\mathrm{F} 1$ races were held in Valencia only five times in the years 2008-2012.
}

1 races in the years 2008-2012) on the other, created islands of poverty and luxury. Public space of el Cabanyal-Canyamelar was filled with contrasts and did not play its integrating social role because 'old' and 'new' residents did not mix at all.

We must conclude that regeneration projects and morphological changes entailed by them only deepened the disintegration of el Cabanyal-Canyamelar. It was followed by unfavourable social and economic consequences, such as, e.g., increased unemployment, accumulation of poverty, social and economic segregation combined with gentrification, higher criminality rates, loose social bonds and stigmatisation of local communities. Nowadays, el Cabanyal-Canyamelar reports social and economic indicators below the average for Valencia (Tab. 3) and the district is considered degraded in spatial, social, economic, and cultural terms (no sense of belonging to the neighbourhood, loss of local identity).

New regeneration projects are currently proposed and undertaken to functionally, economically, socially and culturally revive in particular the central part of el Cabanyal-Canyamelar. These are micro-scale projects often referred to as urban acupuncture (Casagrande \& Harrison 2013; de Solà-Morales i Rubió 1999). Their budget is typically small, comes mainly from public funds and - following the 'right to the city' concept - they focus on the interests of local community, who gets involved at all implementation stages (Lerner 2014). Urban acupuncture projects in el CabanyalCanyamelar emerged from the "Salvem el Cabanyal" social movement. Their goal was to improve the quality of life of the local people and protect cultural objects crucial for the identity of el Cabanyal-Canyamelar and relevant to material and non-material heritage of Valencia. The movement mobilised and increased the awareness of all communities in Valencia (Herrero Garcia \& Soldevilla Llaño 2010). One of the most propagated actions is the one of "Portes Obertes" [Open doors], a kind of an 'open 
Table 2. Changes in the value of real estate (in Euro) and land in el Cabanyal-Canyamelar over the years 2003-2016

\begin{tabular}{|l|c|c|c|c|c|c|c|c|c|}
\hline \multirow{2}{*}{$\begin{array}{c}\text { Average } \\
\text { cadastral value } \\
\text { in thous. } €\end{array}$} & 2003 & 2010 & 2016 & \multicolumn{2}{|c|}{$\begin{array}{c}\text { Change in } \\
2003-2010\end{array}$} & \multicolumn{2}{c|}{$\begin{array}{c}\text { Change in } \\
2010-2016\end{array}$} & \multicolumn{2}{c|}{$\begin{array}{c}\text { Change in } \\
2003-2016\end{array}$} \\
\cline { 5 - 10 } & & & & quantity & {$[\%]$} & quantity & {$[\%]$} & quantity & {$[\%]$} \\
\hline Land & $4,948.85$ & $4,979.60$ & $4,982.35$ & 30.75 & 1 & 2.75 & $0 \%$ & 33.50 & 1 \\
Buildings & $8,883.86$ & $9,651.03$ & $10,027.59$ & 767.17 & 9 & 376.56 & $4 \%$ & $1,143.73$ & 13 \\
Total & $13,832.71$ & $14,630.63$ & $15,009.94$ & 797.92 & 6 & 379.31 & $3 \%$ & $1,177.23$ & 9 \\
Per $\mathrm{m}^{2}$ & 170.74 & 178.96 & 182.19 & 8.22 & 5 & 3.23 & $2 \%$ & 11.45 & 7 \\
\hline
\end{tabular}

Source: Author's compilation based on Catastro de Bienes Inmuebles.

Table 3. Social and economic performance of el Cabanyal-Canyamelar compared to Valencia in 2017

\begin{tabular}{|l|c|c|}
\hline \multicolumn{1}{|c|}{ Indicator } & Valencia & El Cabanyal-Canyamelar \\
\hline Unemployment rate (\%) & 15.90 & 21.60 \\
People drawing all sorts of social benefits (\%) & 25.30 & 26.50 \\
People drawing unemployment benefits (\%) & 8.80 & 42.90 \\
People with primary education (\%) in 2015 & 24.20 & 30.60 \\
Average income per inhabitant (euro) in 2014 & $1,794.95$ & 1804.32 \\
Economically active population (\%) & 62.30 & 61.20 \\
\hline
\end{tabular}

Source: Author's compilation based on Oficina de Estadisticas, Ayuntamiento de València.

museum'. The event is organised every year and goes on for several weekends during which inhabitants of el CabanyalCanyamelar invite visitors to come and see their homes for free. There are also workshops when people can learn about unique architecture of buildings, see local art and traditional craft products as well as taste the local cuisine. The goal is to promote material and non-material heritage of el Cabanyal-Canyamelar to foster local identity and social relationships. The project has come to the attention of other communities in Valencia and tourists to real living conditions in the neighbourhood also in the context of transformations following the implementation of the PEPRI. It also promotes dialogue between private and public spaces. Another example of small scale interventions is the "Passar Sense Trencar" (Passing without Disturbing/Interrupting/Obstacles) project, selected for implementation in 2015 in an international competition for el Cabanyal-Canyamelar regeneration projects. The idea is based on the concept of 'peatonalización', that is the creation of a coherent system of pedestrian passages between different parts of the district. The central part features prominently in the project as it was ruined by the implementation of the PEPRI and Cabanyal 2010 project and urgently needs multifaceted revival. Assumptions of the "Passar Sense Trencar" project provide for the leisure zone to be created on currently idle post-railway areas in the eastern part of el Cabanyal-Canyamelar.

\section{Conclusions}

The above discussed case of el Cabanyal-Canyamelar, a district in Valencia, is an illustration of poorly planned and badly 
implemented mega-scale and top-down regeneration of a dysfunctional (disintegrated) area, which produced even more morphological disintegrating elements that deepened its unfavourable performance. As a result, the area has got degraded and calls for further remedy projects to re-organise the space by eliminating or adapting morphological disintegrators and promote social and economic revival.

Morphology-wise, the main reason behind PEPRI and Cabanyal 2010 plan failure was the fragmentation of Cabanyal-Canyamelar into numerous plots built-up with 19th century buildings, densely built-up and the longitudinal shape of blocks which forced demolition to carry out the construction of the boulevard and introduce green areas. Planned demolition was justified by morphological features of the transformed dysfunctional territory and from this point of view demolition can be considered a rational part of a regeneration project aimed at restoring the organisation of urban space (re-integration) in el Cabanyal-Canyamelar. However, plans to construct Avenida Blasco Ibañez avenue did not take account of the local community views and were mostly subordinated to neoliberal urban policy, which focused on developers' interests and marginalised the interest of local people. Displacements in return for small compensation, disruption of social bonds, social segregation, stigmatisation of local communities, generating conflicts, intentional degradation of buildings later occupied by drug addicts, homeless people, squatters, etc. can be considered another form of demolition. Finally, economic and social functions evaporated and the quality of public space significantly deteriorated, mainly in the area of the planned construction site of Avenida Blasco lbañez.

This state of affairs was also produced by the implementation of large-scale urban redevelopment projects (megaprojects) undertaken, first and foremost, to improve investment and tourist attractiveness of Valencia by organising mega-events in the city. Experiences of many cities across the globe demonstrate that such investment projects, whose spatial and financial scale is usually quite big, may lead to a quantum leap transformation of areas, in which they are carried out and give them a new impulse for further growth (Lorens 2004). As observed by, inter alia, Raco (2014) and Vanwynsberghe et al. (2013) mega-projects connected with regeneration induce changes not only in the transformed areas but also radiate with examples of positive modernisation to the neighbouring areas, which is referred to as the 'Bilbao effect'. In Bilbao, post-industrial areas earmarked for regeneration became the location of Guggenheim Museum, which quickly turned into the iconic landmark of the city. The Museum generated many new jobs in services, from hotels to catering establishments, which enriched city economy. A similar role, although not as spectacular as in the case of Bilbao, is played by new structures erected in relation with mega-events. That is why such investments are often located in dysfunctional areas that need regeneration. In the above discussed case of el Cabanyal-Canyamelar, regeneration that accompanied investment projects linked with mega-events was not an end in itself but a means to an end. As a result, large-scale urban investments (marina and Formula One racing course) did not renovate the district but rather deepened spatial chaos and fostered gentrification and social segregation. Negative effects were reinforced by the then crisis in the real estate market in Spain (Burriel 2011; Estaban \& Altuzarra 2016; Díaz \& Araujo 2017) and ultra-neoliberal policy of municipal authorities to whom spatial planning was much more a tool that supported the implementation of (irrational) development projects (Boira Maiques 2003) rather than a way to take account of the wellbeing of the local community.

Regeneration always entails spatial, economic, social, and cultural costs. Demolition as an element of regeneration speeds up the emergence of costs which in adaptative type of regeneration are distributed over time. Yet, the outcome of regeneration is identical 
in both models, with the exception of morphology as in the adapative model parts of the urban housing stock are transformed rather than eliminated. The idea of dysfunction (disintegration) of urban space does not provide grounds for unambiguous conclusions as to the justification of housing stock demolition as a form of (re)integration. The case of el Cabanyal-Canyamelar highlights the intentions and the course of demolition within the framework of regeneration projects, which should be considered the reference point for future projects in Valencia or in other cities in the world.

\section{References}

Allagra M., Casaglia A., Rokem J., 2012. The political geographies of urban polarization: A critical review of research on divided cities. Geography Compass, vol. 6, no. 9, pp. 560-574.

Andranovich G., Burbank M.J., Heying C.H., 2001. Olympic cities: Lessons learned from mega-event politics. Journal of Urban Affairs, vol. 24, no. 2, pp. 113-131.

Aquilué I., Roca E., 2016. Urban development after the Bosnian War: The division of Sarajevo's territory and the construction of East Sarajevo. Cities, vol. 58, pp. 152-163.

Augé M., 1995. Non-places: Introduction to an anthropology of supermodernity. London: Verso.

Beltran F., 2010. El Cabanyal: Valencia's last window to the Mediterranean. Babelmed, http:// eng.babelmed.net/article/7011-el-cabanyalvalencias-last-window-to-the-mediterranean/ [15 December 2019].

BLANDY S., Lister D., 2005. Gated communities: (Ne)Gating community development? Housing Studies, vol. 20, no. 2, pp. 287-301.

BoIra MaIques J.V., 2003. Science, politics and image in Valencia: A review of urban discourse in the Spanish City. Cities, vol. 20, no. 6, pp. 413-419.

BouRne L.S., 1993. The myth and reality of gentrification: A commentary on emerging urban forms. Urban Studies, vol. 30, no. 1, pp. 312-189.

\section{Acknowledgements}

This work was supported by the National Science Centre of Poland [Grant Number DEC2014/15/B/HS4/01940].

Editors' note:

Unless otherwise stated, the sources of tables and figures are the authors', on the basis of their own research.

Brabec T., Machala B., 2015. The role of developers in the formation of gated communities in Prague. AUC Geographica, vol. 50, no. 2, pp. 115-123.

BURRIEL E.L., 2011. Subversion of land-use plans and the housing bubble in Spain. Urban Research \& Practice, vol. 4, no. 3, pp. 232-249.

Calme J., Charlesworth E., 2012. Divided Cities: Belfast, Beirut, Jerusalem, Mostar, and Nicosia. Philadelphia: University of Pennsylvania Press.

Campos B.S., 2008. Movimientos sociales: una revisión teórica y nuevas aproximaciones. Boletín de Antropología Universidad de Antioquía, vol. 22, no. 39, pp.112-131.

Carvalho M., George R., Anthony K., 1997. Residential satisfaction in Condominos Exclusivos in Brazil. Environment and Behaviour, vol. 29, no. 6, pp. 734-768.

Casagrande M., Harrison A.L., 2013. Architectural theories of the environment: Posthuman territory. New York: Routledge.

Clarke E., 2005. The order and simplicity of gentrification - a political challenge [in:] R. Atkinson, G. Bridge (eds.), Gentrification in a global context: The new urban colonialism, London: Routledge, London, pp. 256-264.

Coudroy de Lille L., 2003. Lyon Confluence metropolitalny projekt w widłach Rodanu i Saony w Lyonie [in:] I. Jażdżewska (ed.), Funkcje metropolitalne $\mathrm{i}$ ich rola $\mathrm{w}$ organizacji przestrzeni, XVI Konwersatorium Wiedzy o Mieście, Łódź: Wydawnictwo Uniwersytetu Łódzkiego, pp. 267-275. 
Davidson M., Lees L., 2005. New-built 'gentrification' and London's riverside renaissance. Environment and Planning A, vol. 37, no. 7, pp. 1165-1190.

De Solà-Morales I Rubió M., 1999. Progettare citta / Designing cities. Milano: Electa.

Del Romeo Renau L., Lozano A.V., 2015. From NIMBYsm to the 15M: A decade of urban conflicts in Barcelona and Valencia. Territory, Politics, Governance, vol. 4, no. 3, pp. 375-395.

Del Romeo Renau L., Trudelle C., 2011. Mega events and urban conflicts in Valencia, Spain: Contesting the new urban modernity. Urban Studies Research, vol. 2011, article ID 587523, 12 pages,. doi:10.1155/2011/587523.

Díaz J.M.C., Araujo J.M., 2017. Historic urbanization process in Spain (1746-2013): From the fall of the American empire to the real estate bubble. Journal of Urban History, vol. 43, no. 1, pp. 33-52.

DUMPer M., 2013. Policing divided cities: Stabilization and law enforcement in Palestinian East Jerusalem. International Affairs, vol. 89, no. 5, pp. 1247-1264.

E.D.U.S.I., 2015. Estrategia de desarrollo urbano sostenible e integrado del barrio. El CabanyalCanyamelar-Cap de Franca. Valencia: Diciembre 2015, http://www.valencia.es/edusi3c/ sites/default/files/docs/e.d.u.s.i._cabanyalcanyamelar-cap_franca_compressed.pdf [20 December 2018].

Estaban M., Altuzarra A., 2016. Local political power and housing bubble in Spain. Investigaciones Regionales: Journal of Regional Research, no. 35, pp. 107-127.

Gaja I Díaz F., 2002. La ciutat de València en el segle XX. La consolidació de la ciutat "moderna" [in:] F. Gaja i Díaz (ed.), Pensar València. Taller XXI d'Urbanisme, Valencia: Universitat Politècnica de València, pp. 1-26.

GEHL J., 2011. Life between buildings: Using public space. Washington D.C.: Island Press.

GiBSON CH., 2003. Cultures at work: Why 'culture' matters in research on the 'cultural' industries. Social \& Cultural Geography, vol. 4, no. 2, pp. 201-215.

GLASS R., 1964. London: Aspects of change. London: Mac Gibbon and Kee, Centre of Urban Studies Report 3.
Gould P., White R., 1974. Mental maps. LondonNew York: Penguin Books.

HalBWACHS M., 1992. On collective memory. Heritage of Sociology Series, Chicago: University of Chicago Press.

Harvey D., 2008. The right to the city. New Left Review, vol. 53, pp: 23-40.

Harvey D., 2012. Rebel cities: From the right to the city to the urban revolution. London: Verso.

Herrero García L.F., Soldevilla Liaño M., 2010. La plataforma Salvem El Cabanyal: doce años de lucha ciudadana. E-rph: Revista electrónica de Patrimonio Histórico, no. 6, pp. 100-116.

JaŁoWIECKI B., SzCZEpańSKI M.S., 2010. Miasto i przestrzeń w perspektywie socjologicznej. Warszawa: Wydawnictwo Naukowe Scholar.

JONES P., EvANS J., 2009. Urban regeneration in the UK. London: Sage.

KaCZMAREKS., 2001. Rewitalizacja terenów poprzemysłowych: Nowy wymiar w rozwoju miast. Łódź: Wydawnictwo Uniwersytetu Łódzkiego.

Kaczmarek S., 2003. Post-industrial areas in modern cities. Bulletin of Geography (Socio-Economic Series), no. 2, pp. 39-46.

Kaczmarek S., 2010. Proces rewitalizacji terenów poprzemysłowych a organizacja przestrzenie miejskiej Łodzi [in:] T. Markowski, S. Kaczmarek, J. Olenderek (eds.), Rewitalizacja terenów poprzemysłowych Łodzi, Warszawa: Biuletyn KPZK PAN, vol. 132, pp. 7-18.

KaczMAREK S., 2012. Kultura gospodarowania przestrzeniq w mieście. Studia Miejskie, vol. 5, pp. 9-17.

KaczmarekS., KazimierczakJ., Coudroy de Lille L., Mongeard L., 2018. Demolowanie terenów miejskich: synergia $w$ badaniach geograficznych w Polsce i we Francji [in:] M. Więckowski, M. Jędrusik, L. Coudroy de Lille, A. Le Blanc (eds.), Geografia. Wspólne idee, wspólne wizje. Sto lat współpracy polsko-francuskiej, Warszawa: Wydział Geografii i Studiów Regionalnych Uniwersytetu Warszawskiego, pp. 97-114.

Kazimierczak J., 2010. Memorial plaques and monuments in Łódź-Śródmieście 'the City Centre District' commemorating people and events from the history of the city. Turyzm, vol. 20, no. 1, pp. 13-19.

KazIMIERCZAK J., 2014. Wpływ rewitalizacji terenów poprzemysłowych na organizacje przestrzeni centralnej w Manchesterze, Lyonie 
i Łodzi. Łódź: Wydawnictwo Uniwersytetu Łódzkiego.

KazIMIeRCZAK J., 2016. Metoda identyfikacji intensywności i typów rewitalizacji terenów poprzemysłowych w procesie kształtowania przestrzeni centralnej miasta na przykładzie wybranych miast europejskich [in:] J. Skowronek (ed.), Innowacyjne rozwiazania rewitalizacji terenów zdegradowanych, vol. 8, Katowice, pp. 111-122.

KazImierczak J., 2017. "Zielona rewolucja": Demolowanie i rewitalizacja w kształtowaniu przestrzeni publicznej miast. Studia Miejskie, vol. 28, pp. 21-43.

Kazimierczak J., Kosmowski P., 2017. In the shadow of urban regeneration megaproject: Urban transitions of downtown in Łódź, Poland. Urban Development Issue, vol. 56, no. 4, pp. 39-50.

KLAAsSen L.H., 1988. Economical Thought and Practice. Łódź: Wydawnictwo Uniwersytetu Łódzkiego.

KOTARBIŃSKI T., 1965. Traktat o dobrej robocie. Warszawa: Zakład Narodowy im. Ossolińskich.

LEES L., 2003. Progress in gentrification research? Afterword. Environment and Planning A, vol. 39, no. 1, pp. 228-234.

LefeBVre H., 1996. Writings on cities. Oxford: Blackwell Publisher.

LERNER J., 2014. Urban acupuncture. Washington: Island Press.

Lévy J., Lussault M. (eds.), 2014. Dictionnaire de la géographie. Paris: Belin.

LISZEWSKI S., 2012. Geografia urbanistyczna. Warszawa: Wydawnictwo Naukowe PWN.

LORENS P., 2004. Tożsamość a autentyzm przestrzeni publicznej współczesnych wielkoskalowych założeń urbanistycznych [in:] T. Markowski (ed.), Wielkoskalowe projekty inwestycyjne jako czynnik podnoszenia konkurencyjności polskiej przestrzeni, Warszawa: Biuletyn KPZK, vol. 210, pp. 10-78.

López Nicolás M., Bodí Ramiro J., 2009. Reordenación urbana, ¿Derechos vulnerados?: El caso del menor en El Cabanyal. Documentos de Trabajo Social, no. 46, pp. 37-55.

LYNCH K., 1960. The image of the city. Cambridge: The MIT Press.

Maik W., Rembowska K., Suliborski A., 2005. Geografia jako nauka o przestrzeni, środowisku i krajobrazie. Łódź: Łódzkie Towarzystwo Naukowe.
MAJer A., 2016. Miasto w osobistym wymiarze. Studia Miejskie, vol. 21, pp. 9-28.

Marcuse P., 2009. From critical urban theory to the right to the city. City, vol. 13, no. 2-3, pp. 185-197.

Miller H.H., 2000. Mega-events, urban boosterism and growth strategies: An analysis of the objectives and legitimations of the Cape Town 2004 Olympic bid. International Journal of Urban and Regional Research, vol. 46, no. 2, pp. 439-458.

Miralles I Garcia J.L., 2013. Contributions to a theoretical framework for sustainable urban development: Some conclusions of the Spanish case [in:] S.S. Zubir, C.A. Brebbia (eds.), The Sustainable City VIII (2 Volume Set): Urban Regeneration and Sustainability, WIT Press, pp. 199210.

Mitchell D., 2003. The right to the city: Social justice and the fight for public space. New York: Guilford Press.

Muñoz Cosme G., 2012. El Cabanyal. Patrimonio En Riesgo. Valencia: Editorial Universitat Politècnica de València.

MuszYŃSKA A., 2013. Wielokulturowość w przestrzeni Suboticy [in:] R. Sendek, B. Rusin (eds.), Wśród czy obok nas? Mniejszości w literaturze, kulturze i historii krajów słowiańskich, Kraków: Wydawnictwo Scriptum, pp. 55-66.

Navarro Elsava L., 2014. Salvem el Cabanyal: Urban movements and their claim for the "Right to the City" in Valencia. VLC arquitectura. Research Journal, vol. 1, no. 2, pp. 47-61.

NaVARRO ElSAVA L., 2016. Urban regeneration and the transformative potential of dissensus: The case of 'el Cabanyal' in Valencia. Conference paper at International Conference: From Contested Cities to Global Urban Justice. Stream 1: Article no. 1-014, Critical Dialogues in Madrid 4 July 2016-7 July 2016.

PAASI A., 2004. Place and region: Looking through the prism of scale. Progress in Human Geography, vol. 28, no. 4, pp. 536-546.

Prytherch D.L., Bolra Maiques J.V., 2009. City profile: Valencia. Cities, vol. 26, no. 2, pp. 103-115.

PurCell M., 2001. Neighbourhood activism among homeowners as a politics of space. Professional Geographer, vol. 53, no. 2, pp. 178-194. 
PURCELL M., 2002. Excavating Lefebvre: The right to the city and its urban politics of the inhabitant. GeoJournal, vol. 58, no. 2-3, pp. 99-108.

Raco M., 2014. Delivering flagship projects in an era of regulatory capitalism: State-led privatization and the London Olympics 2012. International Journal of Urban and Regional Research, vol. 38, no. 1, pp. 176-197.

RelpH E., 1976. Place and placelessness. Research in planning and design, no. 1, London: Pion.

Roche M., 1992. Mega-events and micro-modernization: On the sociology of the new urban tourism. British Journal of Sociology, vol. 43, no. 4, pp. 2-11.

Roche M., 2000. Mega-events and modernity: Olympics and Expos in the growth of global culture. London: Routlege.

Slae B., Kark R., Shoval N., 2012. Post-war reconstruction and conservation of the historic Jewish Quarter in Jerusalem, 1967-1975. Planning Perspectives, vol. 27, no. 3, pp. 369-392.

Swyngedouw E., Moulaert F., Rodriguez A., 2002. Neoliberal urbanization in Europe: Large-scale urban development projects and the new urban policy. Antipode, vol. 34, no. 3, pp. 547-582.
SzMYTKOWSKA M., 2016. Realizacje urbanistyczne $w$ mieście postindustrialnym i ich wpływ na kształtowanie ładu przestrzennego. Studia Miejskie, vol. 22, pp. 9-22.

Tobiasz-LIs P., Wóscik M., 2013a. Evaluating and interpreting the city using a photo projective method: The example of tódź. Geographia Polonica, vol. 86, no. 2, pp. 137-152.

Tobiasz-LIS P., Wóscik M., 2013b. Interpreting contrasts of the post-industrial city: The example of Lodz. International Journal of Humanities and Social Science, Special Issue, vol. 3, no. 14, pp. 22-31.

TUAN Y.-F., 2001. Space and place: The perspective of experience. Minnesota: University of Minnesota Press.

Vanwynsberghe R., Surborg B., Wyly E., 2013. When the games come to town: Neoliberalism, mega events and social inclusion in the Vancouver 2010 Winter Olympic Games. International Journal of Urban and Regional Research, vol. 37, no. 6, pp. 2074-2093.

Waluıs A., 1990. Socjologia przestrzeni. Warszawa: Niezależna Oficyna Wydawnicza.

YIN R.K., 2014. Case study research: Design and methods. London-New Dehli: Sage. 